DIVISION OF THE HUMANITIES AND SOCIAL SCIENCES

CALIFORNIA INSTITUTE OF TECHNOLOGY

PASADENA, CALIFORNIA 91125

ARE AMERICANS AMBIVALENT TOWARDS RACIAL POLICIES?

R. Michael Alvarez

California Institute of Technology

John Brehm

Duke University

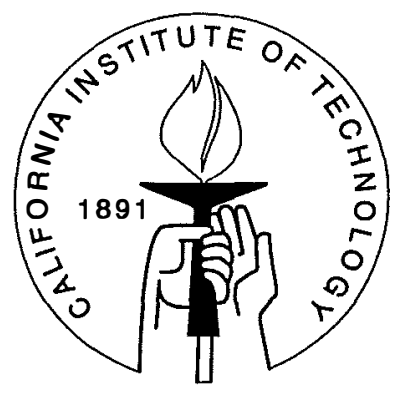

SOCIAL SCIENCE WORKING PAPER 935

July 1995 


\title{
Are Americans Ambivalent Towards Racial Policies?
}

\author{
R. Michael Alvarez John Brehm
}

\begin{abstract}
Few debates, political or academic, are as conflictual as those over racial policy. In this paper, we explore the possibility that individual attitudes are internally conflictual through the use of inferential statistical techniques that estimate variability in individual respondents' considerations about racial policy. We consider six separate core beliefs potentially relevant towards racial policy choice (modern racism, anti-black stereotyping, authoritarianism, individualism, and anti-semitism), for four different policy choices. We evaluate two separate models for the source of individual variance: conflicting values and direct effects of values. Our analysis leads us to conclude that modern racism trumps rival explanatory variables in explanations of racial policy choice, and that variability in attitudes toward racial policy is due to uncertainty, and not to ambivalence.
\end{abstract}




\title{
Are Americans Ambivalent Towards Racial Policies?*
}

\author{
R. Michael Alvarez John Brehm
}

Few contemporary policy debates are as conflictual as those debates over policy intended to redress racial inequality. Elites conflict over the specific terms of policy, over the appropriateness of particular goals, and over the symbols and rhetoric that define the issues. For some individuals, racial policy wears all the signs of a policy debate that yields internal conflict, or ambivalence over policy choices. Our specific research question centers on the sources of individual ambivalence, manifested as greater implicit variation in the range of considerations in response to survey questions.

If one thinks of a survey response as a sample from an individual's range of considerations over policy choice (Zaller 1992), then one of the more important attributes of the range of considerations is its variance (the diversity of potential answers a respondent might supply), as well as its central tendency. Wide variation in responses from an individual might be due to unreflective response manufactured at the door, or it might be symptomatic of internalized conflict over the specific policy domain. The first form of response variability is uncertainty, distinguished from other forms of response variability in that additional information helps the respondent to sharpen his or her opinions. Under uncertainty, response variability is inversely proportional to the respondent's political informedness. The second form of response variability is ambivalence, wherein additional information only heightens the internalized conflict (Liberman and Chaiken 1991; Tetlock 1986), making the policy choices more difficult and responses more variable.

The different origins of response instability are consequential - the doorstep opinion suggests that respondents are ill-equipped to participate in the debate, while the internally conflictual opinion means that the debate itself is difficult. Variation due

*Presented at the 53nd Annual Meeting of the Midwest Political Science Association, April 6-8, 1995, Chicago, IL. We appreciate the comments of Lynn Sanders, Paul Sniderman, Laura Stoker, and the Duke-UNC Political Psychology Group. We thank Paul Sniderman, Philip E. Tetlock and Thomas Piazza for use of their 1991 Race and Politics Survey. Alvarez thanks the John M. Olin Foundation for support of his research. 
to ill-formed responses indicts the respondent or the political process, while variation due to difficult choices identifies the very bone marrow of politics.

As we have argued elsewhere (Alvarez and Brehm 1995), a source for conflict over policy choices can be conflict between core values. If multiple core values pertain to a policy choice, yet they implicate different answers in the debate, then respondents who heed those values will be conflicted in their answers. Difficult policy choices typically involve such conflicts. Abortion policy is difficult for the respondent who prizes a woman's reproductive choice, but also believes that human life begins well before birth. Environmental policy choices are tough for the respondent who values clean air and water, yet regrets imposing any costs on industry that might lead towards the loss of jobs. The decision to go to war against a foreign tyrant is conflictual for those who rue committing American troops to battle.

Do conflicting core values undercut racial policy? According to several prominent scholarly treatments, the answer is in the affirmative. Rokeach (1973) identifies a significant fraction of respondents torn between two terminal values, freedom and equality, over diverse policy choices, including race. Katz and Hass (1988) attribute whites' conflict over racial policy to two competing value orientations, a protestant ethic and a humanitarian-egalitarian orientation. Relatedly, sociological descriptions of American politics turn on two competing core values of individualism and communalism (e.g., Lipset 1967; Williams 1979).

Do these competing core values implicate internalized conflict? Again, the answer in the scholarship appears to be yes. McConahay (1986) argues that the difference between the respondent's reactivity to "old-fashioned" racism scales (racial superiority) and those measuring "modern" racism denotes a zone of ambivalence about race. Katz and Hass (1988) and Katz et al. (1986) argue that white subjects experience psychological tension and discomfort in response to the presence of cues activating conflicted racial attitudes. Gaertner and Dovidio (1986) demonstrate a residual core of aversive racism, even among subjects professing generalized support for racial policy.

To even the most cursory student of the scholarship on racial attitudes, it is bluntly obvious that researchers collide over the basic forces that drive racial attitudes. One group (Kinder and Sears 1981; Kinder 1986; McConahay 1986) contends that "symbolic racism," a combination of anti-black affect with traditional American values, drives white resistance to racial policy. By this argument, whites who oppose such policies as affirmative action or busing on the grounds that blacks are getting more than they deserve, are motivated by a form of racism that has replaced overt expressions of racial superiority. Sniderman and his colleagues (Sniderman and Hagen 1985, Sniderman and Tetlock 1986, Sniderman and Piazza 1993) argue that the symbolic racism fails because it confounds the policy choice with the attitude, while at the same time ignoring the continuing presence of simple anti-black affect as a source of white opposition to racial policy. We take the level of conflict about the 
sources and meaning of white opposition to racial programs as one piece of evidence that individual attitudes may be in conflict.

Both groups of partisans in the debate have direct evidence about individual ambivalence toward race. When one alters the question in relatively minor ways, one can elicit entirely different responses, indeed, even different patterns of responses. Among other persistent differences, Kinder and Sanders (1990) demonstrate through split-form questionnaire that framing the debate as a question of "reverse discrimination" caused egalitarian respondents to see affirmative action as undesirable, whereas a frame of "unfair advantages" caused egalitarians to support affirmative action. Sniderman and Piazza (1993) conclude their book:

Of the myriad findings we have reported on contemporary American racial attitudes, the one to which we ourselves attach the most importance is the pliability of the policy positions of substantial numbers of whites on specific issues of race. It has long been assumed that whites are dug in on racial issues. In fact, large numbers of whites can be dislodged from the positions they have taken on many issues of race by calling their attention to countervailing considerations (p. 178).

The deepest irony of the dispute is that both groups of partisans acknowledge that the framing of the debate determines how respondents will answer questions about racial policy, and that both groups of partisans believe that the lability of response echoes the broader policy debate among elites.

Our point is not to settle, or hardly to enter, the argument over the existence of symbolic racism as a distinct source of racial attitudes. Our specific interest is to assess how levels of support for these values accounts for both the policy choices and the variability of those choices. Our paper has three parts. We first develop six scales for pertinent values from the 1991 Race and Politics survey: symbolic racism, anti-black stereotyping, authoritarianism, anti-semitism, egalitarianism, and individualism. We then turn towards an evaluation of the effect of these values upon policy choices in this survey. Using a heteroskedastic probit model, we look at both the probability of support for the policy and the implicit variance in that probability. Finally, we reflect upon the relationship between internalized conflict at the level of individual survey response to the debate among policy makers.

\section{Measurement of Racial Values}

We construct our core beliefs scales on the basis of the 1991 Race and Politics Survey, a data set collected by the Survey Research Center of the University of California (Berkeley). The survey was a telephone interview based on random-digit dialing using a stratified two-phase sample selection procedure. The first phase of the procedure sampled from known area codes and prefixes, appending a four-digit random number 
to generate a complete ten-digit telephone number. The second phase drew disproportionately from sample strata containing at least one known residential number, although drawing also from strata where there was no known residential number. ${ }^{1}$ The target population consisted of all English-speaking adults over 18 years old, residing in households with telephones, within the 48 contiguous states. The total sample size was 2,223 , with a response rate of $65.3 \%$ (a response rate in excess of typical rates for telephone surveys).

The unique aspect of the Race and Politics Survey was the profusion of split questionnaires, randomly assigned to respondents, made possible by a Computer Aided Telephone Interview approach. Each of the four dependent variables we consider altered important components of the question. For purposes of scale construction, however, we were stymied by the split samples, and employed only those questions which were asked of all respondents.

Six concepts assume varying degrees of prominence in scholarly explanations for variation in racial attitudes. We produce scales for each of the six concepts by the method of confirmatory factor analysis (details of the coding and the confirmatory factor analysis are in Appendix 1). Each scale is coerced to 0-1 bounds, where a 1 denotes the maximum observed level for the scale (e.g., a 1 for authoritarianism denotes a respondent who provides the most authoritarian answers of the sample). We reverse three of the scales (modern racism, authoritarianism, and egalitarianism) to reflect our preference for interpretation of the scales. The reader should note that the maximum and minimum levels for each scale do not reflect absolutes, but only the maximum or minimum observed for the sample. The overall fit for the confirmatory factor model is adequate with a Goodness of Fit Index of 0.86.

The first scale is a measure of "modern racism." According to the various authors (e.g., Kinder and Sears 1981; Kinder 1986; Kinder and Sanders 1990; McConahay 1986) symbolic or modern racism denotes a conjunction of anti-black affect with traditional American values, taking form in the sense that blacks are receiving more attention from government or other advantages than they deserve. ${ }^{2}$

We located three questions which tap into the idea of modern racism. One of these questions is a simple three point Likert scale asking respondents to rate the amount of attention that government has been paying to minorities. The second and third indicators ask how angry the respondent feels about giving "blacks and other minorities special advantages in jobs and schools," and the other about "spokesmen for

\footnotetext{
1 "Known" residential numbers were drawn from a tape created by Donnelly Marketing Services. See Casady and Lepkowski 1991 for further details of the sampling methodology.

${ }^{2}$ McConahay (1986) prefers the term "modern" racism, with the explicit idea that the underlying racial attitudes are possible only in the post civil rights movement period, and because "oldfashioned" racism might also be symbolic (i.e., not grounded in realistic group conflict). Kinder (1986) prefers the term "symbolic" racism, since the "traditional" American values invoked by the idea are hardly "modern." Neither label is perfect. We opt for "modern" racism in the context of the specific questions since all refer (obliquely) to policies only in practice since the 1960s.
} 
minorities who are always complaining that blacks are being discriminated against." The "how angry" variables are scaled from 0 (doesn't bother) to 10 (extremely angry), while the first question is scaled oppositely (from 1 (too much attention) to 5 (not paying enough attention)). Considering the range of the indicators, the indicators load roughly equally on the underlying scale, with estimated factor loadings of -.27 (anger about giving blacks and other minorities special advantages) and -.34 (anger about spokesmen for minorities who are always complaining); the attention to minority problems indicator has been constrained to a coefficient of 1.0.

This scale probably won't satisfy either group of partisans in the debate over the relevance of "modern racism." One of Sniderman and Tetlock's chief objections to the modern racism concept is that the scales often treat policy choices as independent variables in the same models that purport to explain policy choices as dependent variables.

... [I]t is gratuitous to equate opposition to affirmative action with racial prejudice - gratuitous because it would otherwise be possible to examine the actual relation between the two, and thus establish as a matter of fact, and not of definition, how and to what degree the two are connected. Quite simply, defining opposition to affirmative action as racism precludes falsification of the prediction that the two are indeed related, at the cost of making the relation between them a tautology (Sniderman and Tetlock 1986, p. 135).

In order to be sensitive to these objections, we replicate all of our models excluding the modern racism scale. But in defense of the measure, we note that the specific policy referents in the measures are rather oblique. The "attention" variable asks the respondent to evaluate the amount of "attention" from government to the problems of minorities, hardly in the same level of specificity as the dependent variables we discuss later in this paper. The latter two questions ask about a diffuse "anger" provoked by a policy (special advantages) or "complaining" spokesmen.

The weakness in these indicators as seen from the advocates of the symbolic racism concept would be the absence of specific referents to traditional American values. If symbolic racism is the conjunction of anti-black affect and traditional American values, then these questions are decidedly weak as far as their emphasis on "unearned advantages." The language here emphasizes "too much attention" or "special advantages" which orbits somewhere near the meaning of unearned advantages.

The second of these scales is a measure of anti-black stereotyping. Each of the indicators for the anti-black stereotyping scale is a response to a question of the form "How about X? On a scale from 0 to 10 , how well do you think that it describes most blacks?" where the scale ranges from 0 ("very inaccurate") to 10 ("very accurate"). Since this scale is ultimately reversed, each of the factor loadings represents a score in a pro-black direction. The scale performs adequately. All of the negative 
attributes (aggressive, lazy, boastful, irresponsible, complaining) have positive, large, and statistically significant coefficients. ${ }^{3}$

In place of the modern racism scale, Sniderman and Piazza (1993) argue for separate consideration of anti-black stereotyping, and alternative values: authoritarianism, anti-semitism, and individualism. In a series of impressive bivariate analyses, Sniderman and Piazza demonstrate that authoritarianism is more strongly correlated with opposition to racial policy than measures of individualism (which they take to be the core of the modern racism argument).

The authoritarianism scale draws upon six indicators, each of which is a response on a ten point scale to a question of the form "How about X? On a scale from 0 to 10 , how important is that to you?" where 0 denotes "one of the least important things" and 10 denotes "one of the absolutely most important things." (This scale is not reversed.) These six indicators correspond to three aspects of the classic " $F$ scale" of authoritarianism (Adorno et al. 1950, pp. 228-41) - conventionalism, authoritarian submission, and authoritarian aggression - albeit to varying degrees of coherence. "Conventionalism" referred to "rigid adherence to conventional, middle-class values" and is captured here with "Following God's will" and "Improving standards of politeness in everyday behavior." "Authoritarian submission" meant a "submissive, uncritical attitude toward idealized moral authorities of the in-group" and is measured here with "Preserving the traditional ideas of right and wrong." "Authoritarian aggression" referred to a "tendency to be on the lookout for, and to condemn, reject, and punish people who violate conventional values" and is measured by "Respect for authority," "Strengthening law and order" and "Respect for American power." ${ }^{4}$ All six of the loadings for the indicators are strong, where "preserving the traditional ideas of right and wrong" and "respect for authority" are the strongest pair.

Our scale for individualism is measured by three items, two of which are questions of a similar form to those used for the authoritarianism scale (in fact, part of the same battery of questions). "Self-reliance" is scaled at 1, but "emphasizing individual achievement and excellence on the job" scales at only .30. Likewise, "(How about) Government officials interfering and trying to tell us what we can and can't do with our own lives" scales at only .15. This is admittedly a weak scale, and any effect that it has in our subsequent analysis is likely to be attenuated due to the inferior level of measurement.

The next scale that we employ in our analysis measures anti-semitism. Sniderman and Piazza (1993) find modest (approximately .3) correlations between assessments of

\footnotetext{
${ }^{3}$ We have replicated our analysis with a second scale for anti-black stereotyping, where the measures include both positive and negative stereotypes. This alternative scale has some serious defects in that the positive and negative attributes appear to load better on separate scales than on a single scale.

${ }^{4}$ This scale thus omits at least six aspects of the F scale: anti-intraception, superstition, power and toughness, destructiveness and cynicism, projectivity, and sex. One might consider the "respect for American power" question to tap into the "power and toughness" aspect of the F scale.
} 
negative attributes of blacks and agreement with elements of an anti-semitic scale. In several analyses in their book, Sniderman and Piazza utilize anti-semitism as a measure of prejudice because of "[their] believe that the heart of prejudice is captured by the notion of ethnocentrism (p. 107)." We use five Likert scale questions (four point scales which do not include the hedging response of "neither agree nor disagree"). At face value, one of the five questions does not seem to be anti-semitic: "Most Jews are ambitious and work hard to succeed." We have two responses. The reader should recall that the purpose of the scale is to measure a religious stereotype in order to denote prejudice and ethnocentrism. The significant part of the apparently anomalous question is "Most Jews" in light of construction of a stereotype. Our second answer is data-driven: when we delete this question from the scale, the remaining loadings plunge by nearly $25 \%$.

Finally, we construct a scale for "egalitarianism." The nominal conflict between egalitarianism and individualism appears prominently in the literature on attitudes toward racial policy. Katz and Hass (1988) find in experimental work that priming subjects to consider one value or the other significantly increased scores on corresponding attitudes, but not on attitudes corresponding to the non-primed value. In other words, the two scales operate independently, and each has the potential to significantly affect preferences for racial policy. Lipset and Schneider (1978), in a review of a range of survey data, see the dynamic of attitudes towards racial policy as "between two values that are at the core of the American creed - individualism and egalitarianism (43)."

As with our scale for individualism, the scale for egalitarianism is somewhat weak. While the first variable is fixed at 1 (more money being spent to reduce unemployment), the next variable loads at only .33. The non-Likert scale question loads at half that. Again, we expect that the effects of the egalitarianism scale in the estimation will be attenuated.

Finally, we take note of the correlations among these six generated scales (see Appendix 1 for the full correlation matrix). None of the scales are strongly correlated. The highest pairs of correlations include anti-black stereotyping and anti-semitism (.39), and authoritarianism and individualism (.37). Most of the remaining pairs of indicators are correlated at .25 or less. The lack of strong inter-correlations allows us to be more confident that our indicators are indeed tapping into separate dimensions of possible values underlying racial beliefs.

These scales allow us to evaluate the relative weight of the competing explanations for opposition to racial policy, in a mode that is similar to any other analysis of policy choice. But we argue that understanding the choice is only one of the interesting aspects of the problem, and that understanding the variability in that choice, for each respondent, also matters. We employ a heteroskedastic probit technique, simultaneously modeling the probability of a choice and the variability of that probability. The next section details our application of this method. 


\section{Variability of Racial Policy Choices}

The mechanics of the heteroskedastic probit technique may be found in Appendix 2. Briefly, the idea behind the technique is to specify, and simultaneous estimate two related equations, one for the probability of a choice, the other for the variability of that probability. We refer to the first equation as the "Choice Model," and to the second equation as the "Variance Model." The heteroskedastic probit model can be applied to virtually any type of discrete policy choice. For example, in our previous paper we found substantial support for the hypothesis that many Americans are ambivalent, and not uncertain, about abortion policy choices, and that this ambivalence is determined by the conflict between two core values, the value of human life and respect for women's rights (Alvarez and Brehm 1995).

Here we are interested in examining the same hypothesis, except in the context of racial attitudes. As we discussed earlier, there is substantial discussion in the literature about the role that ambivalence plays in racial politics, even for individual choice. What has been absent is a direct examination of the form of the response variability (i.e., uncertainty or ambivalence). Ambivalence as the form of response variability entails two criteria, that individuals who are better informed exhibit greater response variability, because those individuals display conflict between core beliefs or values. Using the 1991 Race and Politics Survey and our heteroskedastic probit technique, we can examine policy choice variability, and evaluate whether it is ambivalence or uncertainty that characterizes variable opinions about racial policies.

\subsection{Choices About Racial Policy}

The 1991 Race and Politics Survey data has extensive data about different racial policy alternatives. In this paper, we focus our attention on only four different types of racial policy choices: federal set-aside programs for minorities, preferences for qualified blacks in university admissions, open housing laws, and whether to raise taxes to increase educational opportunities for minorities. We use only these four since they involved simple dichotomous (yes - no) policy choices. ${ }^{5}$

From the 1991 survey data, we recoded four dependent variables for each type of racial policy choice. The four binary variables are each coded so that 1 indicates an affirmative response (the respondent favors federal set-asides for minorities, they believe that there ought to be preferences for qualified blacks in university admissions, there ought to be open housing laws, and that taxes ought to be raised for educational opportunities for minorities) and 0 indicates a negative response. Given this coding, each of the four heteroskedastic probit models are estimating the probability of an

\footnotetext{
${ }^{5}$ Many of the remaining racial policy choices in this data involved ordered discrete choices. We reserve the analysis of those questions for future work, since the econometrics of a heteroskedastic ordered probit model is beyond the scope of this present research.
} 
affirmative response, and the coefficients we estimate should be interpreted with that in mind.

However, there is one complication we briefly mentioned in the previous section. One of the interesting aspects of the 1991 data involved the use of randomized question experiments which posed different varieties of each question to different respondents (Sniderman and Piazza 1993). That different question wordings were employed in this survey, though, greatly complicates the analysis of these data. To deal with the heterogeneity the question wording experiments impose on each dependent variable, we include in the choice function of each heteroskedastic probit model dummy variables which measure which question wording each respondent received. ${ }^{6}$

The first dependent variable is a three-version question about open housing:

1. (Neutral, Dummy $1=0$, Dummy $2=0,57 \%$ yes): Suppose there were a communitywide vote on a general housing issue and that there were two possible laws to vote on. One law says that homeowners can decide for themselves who to sell their houses to, even if they prefer NOT to sell to blacks. The other law says that homeowners cannot refuse to sell to someone because of their race or color. Which law would you vote for?

2. (Property Rights, Dummy 1=1, Dummy 2=0, 35\% yes): Some people believe that homeowners should be free to decide for themselves who to sell their house to, even if they prefer not to sell it to blacks. For example, some people might say it isn't that they don't want to sell to blacks; it's just that they don't want to be told what to do with their own property. In other words, they feel that because it's their property, they should have the right to sell to anyone they want to.

How do you feel about this? Do you think homeowners should be able to decide for themselves who to sell their hoses to, even if they prefer not to sell to blacks, or do you think homeowners should not be allowed to refuse to sell to someone because of their race or color?

3. (Role of government, Dummy $1=0$, Dummy $2=1,38 \%$ yes): Some people believe that the government should make an active effort to see that blacks can live anywhere they choose, including white neighborhoods. Others believe that this is not the government's business and it should stay of this. How do you feel? (Is this an area the government should stay out of or should the government make an active effort to see that blacks can live anywhere they can afford to including white neighborhoods?)

Both the property rights and role of government frames introduce a rationale for opposing rights of equal access to housing for blacks. The property rights frame invokes one of the very "traditional values" embedded in the modern racism concept, and so advocates of this concept might expect the sign on the coefficient to be negative, and sizable (it is). We do not see the same relationship to the role of government

${ }^{6}$ Although there were many variations in question format, we found few statistically significant interaction effects. That is, the effect of the different question wordings (denoted here by dummies) only shifted the base probability, and did not interact with any of the scales to an appreciable degree. 
frame, although it introduces government intrusion, and a potential reactance effect. The dummy term for the role of government is also negative and sizable. (The coefficient on the role of government dummy is larger than the equivalent for property rights, although the two are statistically indistinguishable).

The second question manipulated a four-version split on set-asides, specifically, federal contracts for black contractors.

1. (Dummy $1=0$, Dummy $2=0,38 \%$ yes) Many people believe ...

2. (Dummy $1=1$, Dummy $2=0,35 \%$ yes) Many blacks believe $\ldots$

3. (Dummy $1=1$, Dummy $2=0,39 \%$ yes) Many people are demanding ...

4. (Dummy $1=1$, Dummy $2=1,38 \%$ yes) Many blacks are demanding ... ... that there should be a law to make sure that a certain number of federal contracts go to black contractors. What do you think about such a law - is it a good idea or a bad idea?

The "people/blacks" frame encourages racists to reject racial policy based on the requester. The "believe/demanding" frame introduces a reactance element. We would have expected that the signs on Dummy 1, Dummy 2, and the interaction of the two would all be negative. Only the coefficient for the "people/blacks" frame is negative, and it is not statistically significant.

The third question is a second four-way split about raising taxes for education, although we opted to fold together responses on one of the splits (not to use the dummy).

1. (Dummy $1=0$, Dummy $2=0,58 \%$ yes) Some people have said that taxes need to be raised to take care of pressing national needs. How do you feel - would you be willing to have your taxes raised a little in order to improve education in public schools?

2. (Dummy $1=1$, Dummy $2=0,62 \%$ yes) Both the President and Congress, including both Democrats and Republicans, have decided that taxes need to be raised to take care of pressing national needs. How do you feel - would you be willing to have your taxes raised a little in order to improve education in public schools?

3. (Dummy $1=0$, Dummy $2=1,51 \%$ yes) Some people have said that taxes need to be raised to take care of pressing national needs. How do you feel - would you be willing to have your taxes raised a little in order to improve educational opportunities for minorities?

4. (Dummy 1=1, Dummy $2=1,64 \%$ yes) Both the President and Congress, including both Democrats and Republicans, have decided that taxes need to be raised to take care of pressing national needs. How do you feel - would you be willing to have your taxes raised a little in order to improve educational opportunities for minorities? 
The first variation in question (Some people/Both the President and Congress) manipulates the status of the advocate. One might expect that the higher status of the President and Congress would induce higher levels of support for policy. Since we saw no direct relevance of the status of the advocate to the racial nature of the question, we neglected to include a dummy. The second question would encourage racists to reject educational opportunities for minorities, since the only significant variation in the question specifies "minorities." The coefficient for Dummy 1 was negative, and sizable.

The final question that we explore in this paper presented two versions of questions related to preference for qualified blacks in university admission.

1. (Preference, Dummy 1=0,31\% yes) Some people say that because of past discrimination, qualified blacks should be given preference in university admissions. Others say that this is wrong because it discriminates against whites. How do you feel - are you in favor of or opposed to giving qualified blacks preference in admission to colleges and universities?

2. (Extra effort, Dummy $1=1,64 \%$ yes) Some people say that because of past discrimination, an extra effort should be made to make sure that qualified blacks are considered for university admission. Others say that this extra effort is wrong because it discriminates against whites. How do you feel - are you in favor of or opposed to making an extra effort to make sure qualified blacks are considered for admission to colleges and universities?

The "preference" frame reflects a stronger policy than simple "extra effort." Hence, we expected the sign on Dummy 1 to be positive, and it was both positive and statistically significant.

\subsection{Specification of the Choice Function}

Other than the dummy variables in the choice function, our specification of this component of the model was driven largely by the existing literature. One group argues that modern racism structures attitudes towards racial policy. Another suggests that the effect of other prejudices should be included, including anti-black attitudes, generalized out-group antipathy (in the form of anti-semitism), and authoritarianism. A third group contends that the conflict of two core values - egalitarianism and individualism - determine racial attitudes.

We allow for six different scales, as discussed in the previous section: modern racism, individualism, anti-black stereotyping, authoritarianism, anti-semitism, and egalitarianism. Each is a scale constructed on the basis of confirmatory factor analysis of various survey items, and each has been recoded to range from 0 to 1 , where 1 indicates the maximum observed level of the scale. Our prior beliefs about the signs on each of the scales is that they should all be negative, with the exception of 
egalitarianism. Higher levels of modern racism, individualism, anti-black stereotyping, authoritarianism, and anti-semitism, and lower levels of egalitarianism, should all be associated with lesser support for racial policy. We additionally include the respondent's self-placement on a liberal-conservative scale as a control in the choice model. We limit the estimates to non-black respondents.

\subsection{Specification of the Variance Function}

The specification of the variance function reflects our desire to test two competing explanations for differences across Americans in the variation of their racial policy beliefs. As we argued above, variation in policy beliefs may reflect fundamental uncertainty about the policy choice under discussion. In other words, people may simply lack information about the policy choices and what they might imply, and that uncertainty will be reflected in the variance function of the heteroskedastic probit model (Alvarez and Franklin 1994; Franklin 1991).

To control for the effect of uncertainty, we include in the specification of the variance function a variable which measures what we call "chronic information." This is a simple political information measure, based on the earlier measures advocated by Zaller (1992). We use an additive scale which measures whether the respondent correctly knew the number of Supreme Court members and the maximum number of presidential terms. This variable is coded to range from 0 to 1 , where 1 indicates correct answers to both factual political information questions. We expect the estimated coefficient to be negative, which implies that with increased political information the amount of variance in policy choices diminishes.

The 1991 survey data also includes three factual items which are race-related: the percentage of poor who are black, the percent arrested who are black, and the percentage of black males who are unemployed. We used responses to these three questions to develop a domain-specific racial information measure. Although the mechanics of the difference are far from clear, chronic information measures regularly outperform domain specific information measures (Zaller 1992).

The rival explanation for variability in attitudes toward racial policy is ambivalence induced by core beliefs underlying racial attitudes. We set two criteria in order to identify ambivalence. The first is that additional information should not reduce, and may in fact heighten, the response variability. The second criteria is that response variability should increase as core beliefs and values conflict. Prior research instructs us to attend to one particular source of conflict, between egalitarianism and individualism. To the extent that racial policies achieve egalitarianism by rejecting individualism, we should expect to see greater response variability among individuals who prize both egalitarianism and individualism.

To test for the core belief conflict, we include the absolute values of the differences 
of levels of egalitarianism and individualism. ${ }^{7}$ To get an intuition for what this operationalization means, recall that each of these core value scales is coded so that the minimum score is 0 and the maximum is 1 . Thus, when we use the absolute value of the differences, when a respondent's level of egalitarianism and individualism are in synch we get a measure of 0 . When the respondent's level of egalitarianism and individualism are completely out of synch (i.e., one is at the maximum, the other is at the minimum), we get a measure of 1 . In this particular case, we expect that if the conflict of the two values structures response variability, then this can only occur when both values are in synch. Hence, if ambivalence is the appropriate characterization, we expect that the coefficient on this measure to be negative and significant.

A second way in which these scales might influence variability in racial attitudes is via a kind of measurement effect. Sniderman and colleagues (Sniderman and Piazza 1993, Sniderman and Hagen 1985, Sniderman and Tetlock 1986) have argued that researchers should not hold that opposition to racial policy is an indication of racism, since opposition to racial policy might be grounded in non-racial objections. This is tantamount to holding that racists are relatively fixed in their opposition to racial policy, but that non-racists might be quite variable in attitudes about racial policy. We estimate a second set of heteroskedastic probit models which include the two primary racial core values, modern racism and anti-black stereotyping, in the variance function. Our expectation is that people who are more racist on these scales will have lower variance, hence that the sign of the direct effects of modern racism and antiblack stereotyping should be negative.

\subsection{Results of the Heteroskedastic Probit Models}

We present our results organized by the specification of the variance function: the "conflict" specification is in Table 1, and the "linear" specification is in Table 2. Each table gives estimates for model coefficients, standard errors, and $\chi^{2}$ tests both for the general fit of the model and for the presence of heteroskedasticity.

Estimation of the choice function yields results which shed light on the current debates about which core beliefs structure choices about racial policies. Across all of the models we estimated, only one of the six scales significantly affected support for racial policy: modern racism. Despite the weaknesses of the particular measure, in every specification of the variance model, for each of the four dependent variables, the modern racism scale is far and away the largest coefficient in the model. In every specification, the modern racism variable is statistically significant at $p<.05$

\footnotetext{
${ }^{7}$ It is conceivable that conflict among the other scales might also lead to greater response variability. An earlier version of this paper, in fact, included all possible combinations of scales in a similar test. None of the results to follow vary significantly with the results of the fully saturated test. We prefer the simpler test of conflict between egalitarianism and individualism as it is one based upon the standing literature. We can think of no similarly motivated reason to expect conflict among any other pair of values.
} 
Table 1: Heteroskedastic probit estimates, 1991 Race and Politics Survey: Conflict Specification of Values

\begin{tabular}{|c|c|c|c|c|}
\hline Variable & Housing & Set-Asides & Taxes & University \\
\hline \multicolumn{5}{|l|}{ Choice Model } \\
\hline Constant & $\begin{array}{c}2.03 * \\
(0.66)\end{array}$ & $\begin{array}{c}1.27 * \\
(0.41)\end{array}$ & $\begin{array}{r}1.87 * \\
(0.60)\end{array}$ & $\begin{array}{c}.91 * \\
(\dot{0} .31)\end{array}$ \\
\hline Dummy 1 & $\begin{array}{r}-0.69 * \\
(0.24)\end{array}$ & $\begin{array}{c}-0.19 \\
(0.12)\end{array}$ & $\begin{array}{c}0.34 * \\
(0.15)\end{array}$ & $\begin{array}{l}1.27 * \\
(0.27)\end{array}$ \\
\hline Dummy 2 & $\begin{array}{r}-0.75 * \\
(0.26)\end{array}$ & $\begin{array}{c}0.10 \\
(0.11)\end{array}$ & $\begin{array}{c}-0.60 * \\
(0.21)\end{array}$ & \\
\hline Dummy $1 \times$ Dummy 2 & & $\begin{array}{c}-0.04 \\
(0.15)\end{array}$ & $\begin{array}{c}-0.33 \\
(0.20)\end{array}$ & \\
\hline Modern Racism & $\begin{array}{c}-1.31 * \\
(0.46)\end{array}$ & $\begin{array}{r}-1.84 * \\
(0.54)\end{array}$ & $\begin{array}{r}-1.80 * \\
(0.57)\end{array}$ & $\begin{array}{c}-2.29 * \\
(0.50)\end{array}$ \\
\hline Individualism & $\begin{array}{c}0.20 \\
(0.29)\end{array}$ & $\begin{array}{r}-1.07 * \\
(0.41)\end{array}$ & $\begin{array}{c}0.69 \\
(0.43)\end{array}$ & $\begin{array}{c}-0.55 \\
(0.30)\end{array}$ \\
\hline Anti-black Stereotypes & $\begin{array}{c}-0.32 \\
(0.28)\end{array}$ & $\begin{array}{c}0.16 \\
(0.29)\end{array}$ & $\begin{array}{c}-0.22 \\
(0.38)\end{array}$ & $\begin{array}{c}0.28 \\
(0.28)\end{array}$ \\
\hline Authoritarianism & $\begin{array}{c}-0.58 \\
(0.30)\end{array}$ & $\begin{array}{c}0.16 \\
(0.26)\end{array}$ & $\begin{array}{c}0.69 * \\
(0.31)\end{array}$ & $\begin{array}{c}0.52 * \\
(0.29)\end{array}$ \\
\hline Anti-Semitism & $\begin{array}{c}-0.55 * \\
(0.26)\end{array}$ & $\begin{array}{r}0.91 * \\
(0.37)\end{array}$ & $\begin{array}{r}-1.04 * \\
(0.38)\end{array}$ & $\begin{array}{c}0.52 * \\
(0.26)\end{array}$ \\
\hline Egalitarianism & $\begin{array}{r}-0.38 * \\
(0.21)\end{array}$ & $\begin{array}{r}-0.54 * \\
(0.26)\end{array}$ & $\begin{array}{c}-1.81 * \\
(0.65)\end{array}$ & $\begin{array}{c}-0.68 * \\
(0.25)\end{array}$ \\
\hline Ideology & $\begin{array}{c}-0.05 \\
(0.03)\end{array}$ & $\begin{array}{c}-0.09 * \\
(0.04)\end{array}$ & $\begin{array}{c}-0.07 * \\
(0.03)\end{array}$ & $\begin{array}{c}-0.07 * \\
(0.03)\end{array}$ \\
\hline Variance Model & & & & \\
\hline Domain Specific Information & $\begin{array}{c}0.55 \\
(0.35)\end{array}$ & $\begin{array}{c}-0.11 \\
(0.22)\end{array}$ & $\begin{array}{c}0.17 \\
(0.28)\end{array}$ & $\begin{array}{c}0.18 \\
(0.22)\end{array}$ \\
\hline Chronic Information & $\begin{array}{r}-0.69 * \\
(0.28)\end{array}$ & $\begin{array}{c}-0.70 * \\
(0.21)\end{array}$ & $\begin{array}{r}-0.74 * \\
(0.25)\end{array}$ & $\begin{array}{c}-0.17 \\
(0.20)\end{array}$ \\
\hline$|E G-I N|$ & $\begin{array}{c}0.34 \\
(0.34)\end{array}$ & $\begin{array}{c}0.48 \\
(0.31)\end{array}$ & $\begin{array}{c}1.10 * \\
(0.33)\end{array}$ & $\begin{array}{c}0.38 \\
(0.23)\end{array}$ \\
\hline Ideology & $\begin{array}{c}0.08 \\
(0.04) \\
\end{array}$ & $\begin{array}{c}0.06 \\
(0.04) \\
\end{array}$ & $\begin{array}{r}0.08 * \\
(0.04) \\
\end{array}$ & $\begin{array}{c}0.01 \\
(0.03) \\
\end{array}$ \\
\hline $\mathrm{N}$ & 1363 & 1396 & 1359 & 1494 \\
\hline$\chi^{2}$ & $192.6 *$ & $223.2 *$ & $199.0 *$ & $403.0 *$ \\
\hline Het. Test & $10.6 *$ & $23.6 *$ & $22.0 *$ & 4.2 \\
\hline
\end{tabular}


Table 2: Heteroskedastic probit estimates, 1991 Race and Politics Survey: Linear Specification of Values

\begin{tabular}{|c|c|c|c|c|}
\hline Variable & Housing & Set-Asides & Taxes & University \\
\hline \multicolumn{5}{|l|}{ Choice Model } \\
\hline Constant & $\begin{array}{r}1.85 * \\
(0.56)\end{array}$ & $\begin{array}{r}1.31 * \\
(0.44)\end{array}$ & $\begin{array}{c}0.81 * \\
(0.29)\end{array}$ & $\begin{array}{l}1.60 * \\
(0.52)\end{array}$ \\
\hline Dummy 1 & $\begin{array}{r}-0.60 * \\
(0.19)\end{array}$ & $\begin{array}{c}-0.18 \\
(0.10)\end{array}$ & $\begin{array}{c}0.14 \\
(0.08)\end{array}$ & $\begin{array}{c}1.82 * \\
(0.46)\end{array}$ \\
\hline Dummy 2 & $\begin{array}{r}-0.66 * \\
(0.21)\end{array}$ & $\begin{array}{c}0.05 \\
(0.08)\end{array}$ & $\begin{array}{c}-0.26 * \\
(0.10)\end{array}$ & \\
\hline Dummy $1 \times$ Dummy 2 & & $\begin{array}{c}-0.03 \\
(0.13)\end{array}$ & $\begin{array}{c}-0.12 \\
(0.10)\end{array}$ & \\
\hline Modern Racism & $\begin{array}{c}-1.13 * \\
(0.37)\end{array}$ & $\begin{array}{c}-1.67 * \\
(0.50)\end{array}$ & $\begin{array}{c}-0.90 * \\
(0.27)\end{array}$ & $\begin{array}{c}-3.01 * \\
(0.81)\end{array}$ \\
\hline Individualism & $\begin{array}{c}0.09 \\
(0.26)\end{array}$ & $\begin{array}{c}-0.83 * \\
(0.33)\end{array}$ & $\begin{array}{c}0.10 \\
(0.18)\end{array}$ & $\begin{array}{c}-1.00 * \\
(0.50)\end{array}$ \\
\hline Anti-Black Stereotypes & $\begin{array}{c}-0.24 \\
(0.22)\end{array}$ & $\begin{array}{c}-0.37 \\
(0.27)\end{array}$ & $\begin{array}{c}-0.06 \\
(0.16)\end{array}$ & $\begin{array}{c}0.25 \\
(0.37)\end{array}$ \\
\hline Authoritarianism & $\begin{array}{r}-0.53 * \\
(0.27)\end{array}$ & $\begin{array}{c}0.07 \\
(0.20)\end{array}$ & $\begin{array}{c}0.32 \\
(0.19)\end{array}$ & $\begin{array}{c}-0.04 \\
(0.40)\end{array}$ \\
\hline Anti-Semitism & $\begin{array}{c}-0.48 * \\
(0.23)\end{array}$ & $\begin{array}{r}0.72 * \\
(0.27)\end{array}$ & $\begin{array}{c}-0.24 \\
(0.16)\end{array}$ & $\begin{array}{c}0.19 \\
(0.34)\end{array}$ \\
\hline Egalitarianism & $\begin{array}{c}-0.40 * \\
(0.23)\end{array}$ & $\begin{array}{c}-1.00 * \\
(0.33)\end{array}$ & $\begin{array}{r}-0.47 * \\
(0.20)\end{array}$ & $\begin{array}{c}-0.94 * \\
(0.40)\end{array}$ \\
\hline Ideology & $\begin{array}{c}-0.04 \\
(0.02) \\
\end{array}$ & $\begin{array}{c}-0.00 \\
(0.00) \\
\end{array}$ & $\begin{array}{c}-0.03 \\
(0.01) \\
\end{array}$ & $\begin{array}{c}-0.06 \\
(0.04) \\
\end{array}$ \\
\hline Variance Model & & & & \\
\hline Domain Specific Information & $\begin{array}{c}0.43 \\
(0.35)\end{array}$ & $\begin{array}{c}-0.11 \\
(0.20)\end{array}$ & $\begin{array}{c}-0.04 \\
(0.26)\end{array}$ & $\begin{array}{c}0.38 \\
(0.24)\end{array}$ \\
\hline Chronic Information & $\begin{array}{c}-0.67 * \\
(0.29)\end{array}$ & $\begin{array}{c}-0.76 * \\
(0.19)\end{array}$ & $\begin{array}{c}-0.72 * \\
(0.24)\end{array}$ & $\begin{array}{c}-0.20 \\
(0.20)\end{array}$ \\
\hline Modern Racism & $\begin{array}{c}-0.17 \\
(0.32)\end{array}$ & $\begin{array}{c}-0.32 \\
(0.32)\end{array}$ & $\begin{array}{c}-1.27 * \\
(0.35)\end{array}$ & $\begin{array}{c}0.51 \\
(0.27)\end{array}$ \\
\hline Anti-Black Stereotypes & $\begin{array}{c}0.44 \\
(0.42)\end{array}$ & $\begin{array}{l}1.26 * \\
(0.41\end{array}$ & $\begin{array}{c}0.71 \\
(0.39)\end{array}$ & $\begin{array}{c}0.46 \\
(0.32)\end{array}$ \\
\hline Ideology & $\begin{array}{c}0.06 \\
(0.04) \\
\end{array}$ & $\begin{array}{c}0.00 \\
(0.00) \\
\end{array}$ & $\begin{array}{c}0.10 * \\
(0.04) \\
\end{array}$ & $\begin{array}{c}0.01 \\
(0.03) \\
\end{array}$ \\
\hline $\mathrm{N}$ & 1363 & 1396 & 1359 & 1494 \\
\hline$\chi^{2}$ & $263.0 *$ & $244.4 *$ & $204.6 *$ & $368.0 *$ \\
\hline Het. Test & $39.6 *$ & $44.6 *$ & $27.6 *$ & $12.0 *$ \\
\hline
\end{tabular}


or better. Furthermore, the coefficient on modern racism is one of only two of the coefficients on the six variables that is always correctly signed (negative). We find this finding to be somewhat ironic, that the modern racism measure performs best, despite significant efforts to measure rival hypotheses. Egalitarianism is also a significant predictor of racial policy choice, such that those respondents who are more egalitarian are more likely to support the racial policy. The coefficients for egalitarianism in the choice models are always significant, although also substantially smaller than the corresponding coefficients for modern racism. ${ }^{8}$

Turning to the remaining four variables, we found that anti-black stereotyping was a consistent predictor of opposition to racial policy for two of the four dependent variables (housing and set asides), although it was statistically significant only for one (housing). Furthermore, we have evaluated the possibility that the collinearity of anti-black stereotyping and modern racism undermined the coefficient for anti-black stereotyping. When we exclude modern racism from the choice model, anti-black stereotyping does not appreciably improve as an explanatory variable.

None of the remaining three scales (individualism, authoritarianism, and antisemitism) achieves any degree of consistency across the four dependent variables. The coefficients on the three variables are often incorrectly signed, although rarely statistically distinguishable from zero.

Our primary interest is in the variance model. We turn first to the heteroskedasticity likelihood ratio test, printed at the bottom of each table. With 4 degrees of freedom, the critical value for the heteroskedasticity likelihood ratio test in the conflict specification is 9.5 (at $p<.05$ ). The first three models exceed the cutoff, implying that responses are heterogenous. The last model (university admissions) does not exceed the critical value, and we cannot reject the assumption of homogeneous response. The linear specification has five degrees of freedom, and the relevant critical value is 11.07 (at $p<.05$ ). Again, we can reject the assumption of homogeneity in the first three models, but not the fourth.

Next, consider the estimated parameters of the variance models. Better (chronically) informed respondents are less ambivalent about racial policy than less informed respondents. The effect of chronic information in the variance model is always negative, and statistically significant at $p<.05$ or better for every variation of the housing and set asides questions. (The coefficient on information is negative for the latter two questions, although only slightly larger than the standard error). The effect of domain specific information, however, is never distinguishable from zero to a statistically

\footnotetext{
${ }^{8}$ When we replicate the analysis without the modern racism measures, there are a few substantive changes. Authoritarianism and anti-black stereotyping become negative, statistically significant variables for each of the four dependent variables under each of the three variance model specifications. To the extent that the modern racism measure "works" because it includes policy choices as evidence of attitudes toward race (i.e., the modern racism measure is endogenous), then one might prefer the specification without modern racism. The substantive results with respect to the variance model are unchanged.
} 
significant degree.

The distinction between "ambivalence" and "uncertainty" is that additional information reduces uncertainty, but does not necessarily reduce ambivalence. If the respondent is in a state of internalized conflict, then additional information only heightens the state of conflict. With attitudes toward abortion policy, we demonstrated that better informed respondents were more ambivalent under "hard" policy choices (where core values were in conflict), and less ambivalent under "easy" policy choices (where one core value dominates).

The consistent negative sign on chronic information implies that variance in attitudes toward racial policy is best characterized by "uncertainty," and not by "ambivalence." Does this finding suggest that the debate on racial policy might actually become consensual, i.e., that variance in attitudes might be reduced? We hold on further interpretation of the effects of chronic information until the conclusion.

The first of our specifications of the variance model (Table 1) posited that individual variance in attitudes toward racial policy was due to conflict between core values of egalitarianism and individualism. For instance, we expected that a respondent who had high, roughly equal levels of esteem for both egalitarianism and individualism would have greater implicit variance in his or her policy choices. The "conflict" model incorporates the absolute value of the difference in two scales. Our expectation was that the signs on the coefficients for these "conflict" terms would be negative.

Instead, all four terms are positive, and one of these to a statistically significant degree. (We obtain a similar pattern from a fully saturated set of conflict terms among the six scales). Overall, one would have to conclude that conflict between core values does not account for variance in attitudes, with conflict measured in this way.

We set two criteria to distinguish ambivalence from uncertainty: that the effect of information is to increase ambivalence, because dissonance in core beliefs should be irresolvable. With respect to the four measures of attitudes toward racial policy in this essay, we found exactly the opposite: information reduces individual variance, and there was no evidence of conflict in core values as a source of variance.

An alternative conception of the variance in attitudes toward racial policy is that the "fit" of attitudes toward racial policy as a function of racial attitudes varies by the level of racial attitudes. In other words, racists might have little variance in opposition to racial policy, but that non-racists might be quite variable in support for racial policy, since opposition to that policy might be grounded in nonracial foundations. In order to evaluate this conception, we include direct effects of modern racism and antiblack stereotyping (the two strongest predictors of opposition to racial policy) in the variance model (Table 2). If this alternative conception holds, we would expect that the signs on the variance coefficients for modern racism and anti-black stereotyping should be negative, i.e., that higher levels of each lead to less variance. 
Overall, this argument for the source of individual variation fails. Of the eight coefficients on the direct effects, three are negative, and only one of these to a statistically significant degree. None of the measures of anti-black stereotyping are either negative nor significant. But there is some indication that the argument might hold for modern racism. Three of the four terms on modern racism are negative, one to a statistically significant degree. The fourth model is also not heterogeneous, by the likelihood ratio test. An implication of this frankly provisional result is that it is touchy to infer from opposition or support for racial policy back to racial attitudes. With at least two of the four policy choices (set asides and taxes), those who were lowest on the modern racism scale were of widest variance in their choices, meaning that those who were, by this measure, not racist might still be in opposition to policy.

\subsection{Magnitude of Estimated Effects}

The estimated effects of racial values and different specifications of heterogeneous responses allow only for rough tests of the hypotheses we have presented earlier. Just as with more common binary choice models, the heteroskedastic probit parameters are difficult to interpret on their own. Here we turn to another way of presenting the estimated effects of racial values and ideology upon policy choice, by examining the "first differences" for each of the important right-hand side variables.

The "first difference" methodology is relatively simple (King 1989). Here we set each right-hand side variable to the sample mean value; with these values and the estimated coefficients, we can determine the probability that a hypothetical respondent would give a particular answer to a survey question. Then, for a particular independent variable (say modern racism in the housing model), we increase the value of that variable by two sample standard deviations, and then calculate the probability that this hypothetical respondent gave an affirmative answer to the housing question. The difference between these two probability estimates provides our "first difference" which can also be thought of as an estimate of the impact of a two standard deviation change in one independent variable, holding all other effects in the model constant.

These "first differences" are presented for both of the specifications (given on the left) in Table 3. Recall that with the coding of the racial value scales, we expect to see positive "first differences" (indicating that the probability of affirmative response is greater for the first calculation [the mean] than the second [the mean plus two standard deviations]) for modern racism, individualism, anti-black stereotyping, authoritarianism and anti-semitism, but negative "first differences" for egalitarianism.

The probability differences in Table 3 do shed additional light on the debates surrounding which core beliefs impact racial policy choices. Here is strong evidence that modern racism is the predominant variable which structures racial policy choices, specifically policies dealing with housing, set-asides, taxation and university admissions. Modern racism's weakest effects are in the housing models, where a two stan- 
Table 3: Effects of Values and Ideology from Heteroskedastic Probit Models

\begin{tabular}{lrrrc}
\hline \hline Variable & Housing & Set-Asides & Taxes & University \\
\hline Conflict Specification & & & & \\
Modern Racism & .16 & .19 & .16 & .28 \\
Individualism & -.02 & .10 & -.04 & .05 \\
Anti-Black Stereotypes & .04 & -.02 & .02 & -.03 \\
Authoritarianism & .06 & -.02 & -.05 & -.06 \\
Anti-Semitism & .07 & -.13 & .09 & -.06 \\
Egalitarianism & .05 & .07 & .16 & .09 \\
Ideology & .06 & .10 & .06 & .09 \\
\hline Linear Specification & & & & \\
Modern Racism & .16 & .19 & .21 & .24 \\
Individualism & -.01 & .08 & -.02 & .07 \\
Anti-Black Stereotypes & .03 & .04 & .01 & -.02 \\
Authoritarianism & .06 & -.008 & -.06 & .003 \\
Anti-Semitism & .07 & -.10 & .06 & -.02 \\
Egalitarianism & .06 & .12 & .11 & .08 \\
Ideology & .05 & .00 & .07 & .05 \\
\hline Note: From heteroskedastic probit estimates in Tables 1-2. \\
\hline \hline
\end{tabular}

dard deviation increase in the modern racism scale leads to .13 to .16 drop in the probability that the respondent would support open housing laws. But an identical change in the modern racism scale leads to almost doubling on the drop in probability that the same hypothetical respondent would support affirmative action university admissions (.23 to .28 changes in probability). No other variable comes close to having this impact on racial policy choices.

The estimated parameters in the variance function are also difficult to interpret. In Table 4 we present calculations which will allow us to discuss the magnitude of the estimated effects on the variation in respondent policy choices. Here we follow the logic of the "first difference" approach by estimating the underlying error variance for the same hypothetical respondent (mean values of all right-hand side variables), with one of the error variance terms set to 0 . We then estimate the error variance again, after changing that same variable to the maximal value ( 1 for the information and value terms, 6 for ideology), while holding the other variables constant. In Table 4 we give the difference between these two calculations. Again, we are interested in determining what impact a significant change in each independent variable has on the magnitude of the error variance.

Among the two information variables, the inconsistent effects of domain specific information can again be seen. In three of the models race specific information has an effect opposite that we posited - higher race specific information leads to higher levels of error variance. In only the set-asides model do we see race specific information with the correctly signed effect, but it appears to have a relatively small magnitude. 
Table 4: Effects of Variables on Error Variance

\begin{tabular}{lrrrr}
\hline \hline Variable & Housing & Set-Asides & Taxes & University \\
\hline Conflict Specification & & & & \\
Domain Sp. Info. & .81 & -.12 & .31 & .23 \\
Chronic Info. & -.90 & -.80 & -1.35 & -.21 \\
$|E G-I N|$ & .42 & .51 & 1.84 & .46 \\
Ideology & .08 & .06 & .11 & .01 \\
\hline Linear Specification & & & & \\
Domain Sp. Info. & .53 & -.11 & -.03 & .72 \\
Chronic Info. & -.75 & -.84 & -.50 & -.34 \\
Modern Racism & -.19 & -.35 & -.98 & .86 \\
Anti-Black Stereotypes & .48 & 1.39 & .48 & .79 \\
Ideology & .39 & .00 & .40 & .10 \\
\hline Curvilinear Specification & & & & \\
Domain Sp. Info. & .40 & -.33 & .007 & .72 \\
Chronic Info. & -.58 & -1.81 & -.53 & -.33 \\
Modern Racism & -1.19 & -6.17 & -.86 & -2.01 \\
Anti-Black Stereotypes & -.53 & -1.67 & -.48 & -.30 \\
Ideology & .38 & .47 & .37 & .00 \\
\hline Note: From heteroskedastic probit estimates in Tables 1-2. \\
\hline \hline
\end{tabular}

But chronic political information consistently has the correct effect, with more chronic information leading to lesser error variance. The estimated effects are consistent across the different dependent variables and the different error variance specifications. And compared to most of the other error variance effects, chronic information has a consistently large effect.

What can these calculations tell us about the different specifications of racial core beliefs? The first specification we presented we called the "conflict specification," which estimated the effects of the conflict between egalitarianism and individualism and posited that individuals with greater conflict ought to lead respondents to have higher error variances (recall that with the coding of these two scales, the absolute value of their differences leads to variable in which conflict is coded 0 and agreement is coded 1). In Table 4 we see that the estimated effects on the error variance of this specification are incorrectly signed, and that they even are larger than the effects of chronic political information in two models (taxes and university admissions).

The second specification was the linear specification of modern racism and antiblack stereotypes. Increases in both of these variables ought to decrease error variance. Only three of the estimates (modern racism in the housing, set-asides and taxes models) conform to this expectation. None of the anti-black stereotype effects are correctly signed, and again one is of considerable magnitude relative to chronic information (set-asides).

In general, several conclusions can be taken from these empirical results. First, 
as far as choices about these four racial policies are concerned, they are largely a function of modern racism. Second, we have shown that three of these four racial policy alternatives provoke heterogeneous responses (housing, set-asides and taxes). And last, our results indicate that the variability in respondent choices about racial policies is more due to uncertainty than to conflicting core beliefs.

\section{Conclusion}

In short, we find evidence to rile both sides of the debate on racial attitudes. The principal disagreement is over the importance of modern racism, where one camp holds that the modern racism measure neglects the effects of rival hypotheses: antiblack stereotyping, individualism, generic out-group dislike (proxied here with antisemitism), and authoritarianism. The modern racism measure is substantively the most important predictor of attitudes toward racial policy. Yet we also found that it may be difficult to infer back from opposition to the policy to the attitudes, since those who were least racist by the modern racism measure were more likely to be "accidentally" in opposition to the policy.

We also found evidence that the one point of agreement between the two sides might be in error. Both camps agree that attitudes toward racial policy are highly sensitive to question wording, and that ambivalence characterizes much of American attitudes toward racial policy. Yet if we distinguish ambivalence from other forms of individual variability in attitudes by the role of information and the underlying conflict in core beliefs, "ambivalence" is probably the wrong term. Additional information reduced individual variance, and there was scant evidence that conflict in racially relevant attitudes led to greater variability. "Uncertainty" seems like the better word to us.

That the individual variability in attitudes toward racial policy stems from uncertainty, and not ambivalence, has significant political implications. If we had found that ambivalence towards racial policies in the minds of Americans was tied directly to their core beliefs, then the only way to resolve this ambivalence politically would be to change the underlying core beliefs. This would certainly seem a difficult task.

On the other hand, we found that the variability in attitudes toward racial policy grow largely out of uncertainty. This is consistent with past research:

The most important thing to appreciate about the thinking of whites on race, we now believe, is that many of them do not very often think about it at all ... But there are good reasons why whites might not make the issue of race central to their concerns. They neither suffer directly from the problem of racial inequality, nor see themselves as directly responsible for it. The problem of race is, like many other problems of public policy, 
a secondary concern in the daily lives of whites and of only occasional interest to them (Sniderman and Piazza 1993: 154).

The political implications, then, are that to change the minds of many Americans about racial policies it is necessary to reduce their uncertainty about the policies.

This does not mean that, though, that the reduction of variability in racial attitudes lead to consensus in public opinion about the "correct" direction of racial politics. While Americans would become more rooted in their opinions about public policy, roughly equal numbers could be rooted on opposite ends of any racial issue, which would be difficult to resolve politically.

So, there are no easy answers to the dilemma of race in American politics. While we found that opinions about abortion policies were ambivalent due to conflicting core beliefs, we have shown here that opinions about racial policies are not ambivalent, but due to uncertainty. That does not make the resolution of debates about either issue any easier to resolve, nor does it make the search for general models of public opinion any more tractable.

Why is it that attitudes toward abortion appear to be ambivalent, while those toward racial policy appear to be better characterized as uncertain? We offer some speculations at this point. Perhaps problems of ambivalence arise when there are incommensurable choices. In the case of abortion policy, the choices are clear and stark. One can either permit the abortion of the fetus, or one requires the mother to carry the fetus to term. Racial policy, perhaps, permits compromises. Setting aside some contracts for black-owned businesses, making some allowances for higher taxes for minority schools, admitting some black students under affirmative action guidelines may not do grievous damage to principles of individualism, while perhaps accommodating a more egalitarian policy. 


\section{Appendix 1: Coding of Variables and Confirma- tory Factor Analyses Results}

We employed the following coding scheme prior to the confirmatory factor analysis:

Modern Racism: "Attention to minority problems" is scaled from $1=$ too much attention, $3=$ About the right amount, $5=$ Not paying enough attention. "Anger about giving blacks and other minorities special advantages" and "Anger about spokesmen for minorities who are always complaining" are scaled from 0 "doesn't bother you at all" to 10 "makes you extremely angry and upset."

Anti-black Stereotyping: All variables are answers to questions of the form "(How about) X?" On a scale from 0 to 10 , how well do you think it describes most blacks?" where 0 is "very inaccurate" and 10 is "very accurate." The traits in X included "Aggressive or violent," "Lazy," "Boastful," "Irresponsible," and "Complaining."

Authoritarianism: All variables are answers to questions of the form "(How about) X?" On a scale from 0 to 10 , how important is that to you?" where 0 is "one of the least important things" and 10 is "one of the absolutely most important things." The set $\mathrm{X}$ included: "Preserving the traditional ideas of right and wrong," "Respect for authority," "Following God's will," "Improving standards of politeness in everyday behavior," "Strengthening law and order," and "Respect for American power."

Individualism: The first two variables are answers to questions of the form "(How about) X?" On a scale from 0 to 10 , how important is that to you?" where 0 is "one of the least important things" and 10 is "one of the absolutely most important things." The set X included "Self-reliance" and "Individual job achievement and excellence." The last variable is an answer to a question "On a scale from zero to ten, how much does 'Interfering Government officials' anger you?"

Anti-semitism: All variables are answers to four point Likert scale questions, where $1=$ Agree strongly, $3=$ Agree somewhat, $5=$ Disagree somewhat, and $7=$ Disagree strongly. The questions included "Most Jews are ambitious and work hard to succeed," "Most Jews are more willing than other people to use shady practices to get ahead in life," "Most Jews believe that they are better than other people," "Most Jews in general are inclined to be more loyal to Israel than to America," and "Most Jews don't care what happens to people who aren't Jewish."

Egalitarianism: The first two questions are answers to four point Likert scales, ranging from (1) strongly in favor, (3) somewhat in favor, (5) somewhat opposed, and (7) strongly opposed. The questions were "How about 'more money being spent to reduce unemployment?' " and "How about 'narrowing the gap in income between the rich and the poor?' " The last variable is an answer to a question "(How about) When people are treated unfairly because of their race? On a scale from zero to ten, how much does this anger you?" 
Table 5: Confirmatory factor loadings for scales, 1991 Race and Politics Survey

\begin{tabular}{lr}
\hline Variable & Loading \\
\hline Modern Racism & \\
Attention to minority problems & 1.00 \\
Anger about giving blacks and other minorities special advantages & -.27 \\
Anger about spokesmen for minorities who are always complaining & -.34 \\
& \\
Anti-Black Stereotyping & 1.00 \\
Aggressive or violent & .87 \\
Lazy & .63 \\
Boastful & .77 \\
Irresponsible & .68 \\
Complaining &
\end{tabular}

\section{Authoritarianism}

Preserving the traditional ideas of right and wrong $\quad 1.00$

Respect for authority $\quad .91$

Following God's will $\quad .74$

Improving standards of politeness in everyday behavior $\quad .71$

Strengthening law and order $\quad .76$

Respect for American power $\quad .78$

Individualism

Self-reliance $\quad 1.00$

Individual job achievement and excellence $\quad .30$

Interfering Government officials $\quad .15$

Anti-Semitism

Most Jews are ambitious and work hard to succeed $\quad 1.00$

Most Jews are more willing than other people to use shady practices to get ahead in life $\quad .85$

Most Jews believe that they are better than other people $\quad .90$

Most Jews in general are inclined to be more loyal to Israel than to America $\quad .76$

Most Jews don't care what happens to people who aren't Jewish $\quad .86$

\section{Egalitarianism}

How about "more money being spent to reduce unemployment?" $\quad 1.00$

How about "narrowing the gap in income between the rich and the poor?"

(How about) When people are treated unfairly because of their race?

Cell entries are factor loadings. Scales derived from the confirmatory factory models are coerced to the range $0-1$, with modern racism, authoritarianism, and egalitarianism reversed. All coefficients are significant at $p<.01$. 


\section{Appendix 2: Heteroskedastic Probit as a Tool for Understanding Conflictual Attitudes}

A more thorough review of the mechanics of heteroskedastic probit may be found in our paper (Alvarez and Brehm 1995), as well as in one prominent econometrics text (Greene 1993). Each of the dependent variables we consider in the next section of this paper is dichotomous, leading towards the usual probit or logit likelihood:

$$
\log L(\pi \mid y)=\sum_{i=1}^{N} y_{i} \log \pi_{i}+\left(1-y_{i}\right) * \log (1-\pi)
$$

Where $\pi$ is reparameterized as a function, $f()$,(usually a probit or logit function) of a set of explanatory variables $(X)$ :

$$
\pi_{i}=f\left(X_{i} \beta\right)
$$

We refer to this function (2) as the "choice model." The standard probit or logit assumes that the variance of the choice function is constant, and can be standardized to 1.

Our innovation is to notice that choice is sometimes heterogeneous, that the underlying variance of the choice function is not constant. Borrowing from Harvey's 'multiplicative heteroskedasticity' approach (1976), we reparameterize the variance for an individual's choice $\left(\operatorname{var}\left(\epsilon_{i}\right)\right)$ as a function of an additional set of explanatory variables $(Z)$ :

$$
\operatorname{var}\left(\epsilon_{i}\right)=\exp \left(Z_{i} \gamma\right)^{2}
$$

(Exponentiation is required in order to keep variance greater than zero). We refer to this second function (3) as the "variance model."

This leads to a variation on the usual probit log-likelihood:

$$
\log L=\sum_{i}\left(y_{i} \log \Phi\left(\frac{X_{i} \beta}{\exp ^{Z_{i} \gamma}}\right)+\left(1-y_{i}\right) \log \left[1-\Phi\left(\frac{X_{i} \beta}{\exp ^{Z_{i} \gamma}}\right)\right]\right)
$$

We have successfully estimated this function using Gauss and Shazam, two popular econometrics packages.

There is an implicit test for the presence of heterogeneity with the addition of the variables in the denominator to the likelihood. If the variables in the variance function in the denominator add no new information, then the likelihood for the heteroskedastic probit (4) will not be appreciably different from the likelihood for the standard probit (1). The test is then

$$
L R=2 \times\left(L_{H}-L_{S}\right)
$$

where $L_{H}$ is the $\log$-likelihood for the heteroskedastic probit (4), and $L_{S}$ is the loglikelihood for the standard probit (1). The $L R$ is distributed as a $\chi^{2}$ with as many degrees of freedom as there are $Z$ variables. 


\section{References}

Adorno, T.W., Else Frenkel-Brunswik, Daniel J. Levinson, and R. Nevitt Sanford. 1950. The Authoritarian Personality, Part One, New York: John Wiley \& Sons.

Alvarez, R. Michael and John Brehm. 1995. "American Ambivalence Toward Abortion Policy: A Heteroskedastic Probit Method for Assessing Conflicting Values." American Journal of Political Science, forthcoming.

Alvarez, Ramon Michael and Charles H. Franklin. 1994. "Uncertainty and Political Perceptions." Journal of Politics, forthcoming.

Casady, R.J. and J.M. Lepkowski. 1991. "Optimal Allocation for Stratified Telephone Survey Designs," Proceedings of the Section on Survey Research Methods, American Statistical Association.

Franklin, Charles H. 1991. "Eschewing Obfuscation? Campaigns and the Perceptions of U.S. Senate Incumbents." American Political Science Review, 85: 1193-1214.

Gaertner, S.L. and J.F. Dovidio. 1986. "Aversive Racism." In J.F. Dovidio and S.L. Gaertner (Eds.) Prejudice, discrimination, and racism. New York: Academic Press.

Greene, William H. 1993. Econometric Analysis, 2d Edition. New York: MacMillan Publishing Company.

Harvey, Andrew. 1976. "Estimating Regression Models with Multiplicative Heteroscedasticity," Econometrica, 44:461-465.

Katz, Irwin, and R. Glen Hass. 1988. "Racial Ambivalence and American Value Conflict: Correlational and Priming Studies of Dual Cognitive Structures," Journal of Personality and Social Psychology, 55:893-905.

Katz, Irwin, J. Wackenhut, and R. Glen Hass. 1986. "Racial ambivalence, value duality, and behavior." In J.F. Dovidio and S.L. Gaertner (Eds.) Prejudice, discrimination, and racism. New York: Academic Press.

Kinder, Donald R. 1986. "The Continuing American Dilemma: White Resistance to Racial Change 40 Years After Myrdal." Journal of Social Issues, 42:151-71.

Kinder, Donald R. and David O. Sears. 1981. "Prejudice and politics: symbolic racism versus racial threats to the good life." Journal of Personality and Social Psychology, 40:414-31.

Kinder, Donald R., and Lynn M. Sanders. 1990. "Mimicking political debate with survey questions - the case of white opinion on affirmative action for blacks." Social Cognition 8: 73-103.

Liberman, Akiva and Shelly Chaiken. 1991. "Value Conflict and Thought-Induced Attitude Change." Journal of Experimental Social Psychology 27:203-16. 
Lipset, Seymour Martin and William Schneider. 1978. "The Bakke Case: How Would It Be Decided at the Bar of Public Opinion?" Public Opinion, (March/April): $38-44$.

McConahay, John B. 1986. "Modern racism, ambivalence, and the modern racism scale." In J. Dovidio and S.L. Gaertner (Eds.), Prejudice, discrimination, and racism: Theory and research, New York: Academic Press.

Rokeach, M. 1973. The nature of human values. New York: Free Press.

Sniderman, Paul M. and M. Hagen. 1985. Race and Inequality, New York: Chatham House.

Sniderman, Paul M. and Thomas Piazza. 1993. The Scar of Race, Cambridge: The Belknap Press of Harvard University.

Sniderman, Paul M. and Philip E. Tetlock. 1986. "Symbolic Racism: Problems of Motive Attribution in Political Analysis." Journal of Social Issues, 42:129-50.

Tetlock, Philip E. 1986. "A Value Pluralism Model of Ideological Reasoning." Journal of Personality and Social Psychology 1986:819-27.

Zaller, John. 1992. The Nature and Origins of Mass Opinion. Cambridge, Mass.: Cambridge University Press. 